\title{
The 1719 El Salvador Earthquake: An M >7.0 Event in the Central American Volcanic Arc?
}

\section{by Çarolina Canora, José J. Martínez-Díaz, Juan M. Insua-Arévalo, José A. Álvarez-Gómez, Pilar Villamor, Jorge Alonso-Henar, and Ramón Capote-Villar}

\section{INTRODUCTION}

In the regions where few field neotectonics and paleoseismic studies have been performed (e.g., Central America), the interpretation of the seismic sources responsible for the historical (preinstrumental) catastrophic earthquakes lies almost entirely in the spatial distribution of damage interpreted from historical sources, mainly fragmentary written documents. The occurrence of catastrophic earthquakes affecting this region justifies the necessity of a deeper analysis of the geologic implications of the more significant historical earthquakes in light of the new insights. Recent advances in the identification and dating of surface-rupture evidences along the central El Salvador volcanic arc led us to revisit some historical evidence of damage along this region and to combine geologic (paleoseismic) evidence with damage distribution.

At least 11 destructive earthquakes have occurred in El Salvador since 1900 (White and Harlow, 1993; Fig. 1). These events caused more than 3000 deaths as a consequence of strong ground motions and/or subsequent landslides (Bommer et al., 2002). The instrumental earthquake record shows that large $\left(M_{\mathrm{w}}>7\right)$ events occurred as reverse fault events along the interface between the subducted plate and the over-riding continental plate or as normal-faulting events within the subduction plate resulting from extensional forces generated by slab-pull forces or by bending of the subduction plate (Álvarez-Gómez, 2009). Onshore, instrumental earthquakes have been reported with moderate magnitudes $\left(M_{\mathrm{w}}<6.6\right)$ in association with the highly seismic volcanic arc area. Preinstrumental historical records larger than $M_{\mathrm{w}}>7.0$ usually have been assigned to the subduction zone, whereas historical records with $M_{\mathrm{w}}<7.0$ have been assigned to the volcanic arc regions (White et al., 1987; Dewey and Suárez, 1991; Harlow et al., 1993; White and Harlow, 1993). However, paleoseismic studies provide evidence of large earthquakes $\left(M_{\mathrm{w}}>7.0\right)$ associated with the rupture of the $\mathrm{El}$ Salvador fault zone (ESFZ; Canora et al., 2012). This fault zone has a complex structure composed five segments, dominated by east-west to east-southeast-west-northwest strike-slip faults. The total structure extends for $150 \mathrm{~km}$ through central El Salvador. Some of those large surface-rupture events are dated to the eighteenth century and later, opening the possibility of reinterpreting historical destructive events that were previously located using only damage distribution.

The last two destructive earthquakes occurred on 13 January and 13 February 2001. The $M_{\mathrm{w}} 7.7$ January event ruptured part of the subducting plate and caused around 944 deaths in El Salvador, mainly from triggered landslides (Bommer $e t$ al., 2002). The $M_{\mathrm{w}} 6.6$ February event struck the central part of El Salvador and caused another 315 deaths, thousands more injuries, and extensive damage (Fig. 1). This earthquake was associated with the reactivation of the San Vicente segment of the ESFZ (Canora et al., 2010).

The ESFZ is a major structure in the Central American volcanic arc associated with high rates of historical seismicity. Global Positioning System velocity data indicate strain accumulation rates of $9-10 \mathrm{~mm} / \mathrm{yr}$ for the ESFZ (Alvarado et al., 2011). The San Vicente segment is an east-west-oriented right-lateral strike-slip fault that extends more than $20 \mathrm{~km}$ from the Ilopango caldera to the city of San Vicente (Fig. 2a). Paleoseismic studies undertaken on this fault segment after the 2001 earthquake (Canora et al., 2012) found only subtle evidence of the 2001 rupture in the trenches but substantially large coseismic displacements for previous events, suggesting that prior ruptures along the ESFZ could have been associated with earthquakes much larger than the $2001 M_{\mathrm{w}} 6.6$ event.

In this paper, we analyze a new trench excavated at the site on the ESFZ with the highest surface expression of the February $2001 M_{\mathrm{w}} 6.6 \mathrm{El}$ Salvador earthquake, in order to compare the event displacement with the magnitude. Then we review the historical record of destructive earthquakes in El Salvador, reinterpret the damage distribution, and compare them with the previous paleoseismic event displacements and ages to evaluate if any of those large historical events occurred on the ESFZ. We also construct a new isoseismal map for the 6 March 1719 earthquake that suggests the damage reported could have been a consequence of rupture of the ESFZ rather than of subduction zone. We thus challenge the traditional assumption that only the subduction zone is capable of generating earthquakes of magnitude greater than 7.0 in this region.

The assumption of a greater maximum potential magnitude than that considered until now for earthquakes associated with the faults located along the Salvadorian volcanic arc has 


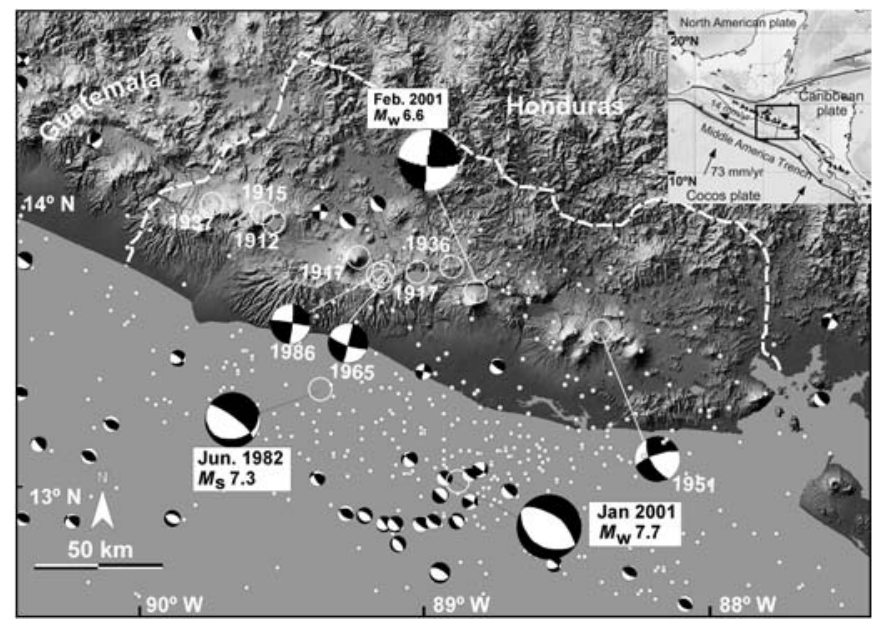

A Figure 1. Shuttle Radar Topography Mission image of El Salvador with locations of historically destructive earthquakes and instrumental earthquake epicenters (period 1977-2001) from the U.S. Geological Survey's National Earthquake Information Center catalog. Smaller focal mechanism symbols are for events of $M_{\mathrm{w}}>5.5$ (1977-2001; Global [formerly Harvard] Centroid Moment Tensor database), and larger focal mechanism symbols are for events of $M_{\mathrm{w}}>6.5$ (from Buforn et al., 2001). The white dashed line shows the El Salvador border. The inset shows the study area location with the tectonic plates, major crustal blocks, and faults of northern Central America. The arrows show relative displacements.

important implications in seismic-hazard assessments in this region.

\section{PALEOSEISMICITY: FINDING LARGE EVENTS ALONG THE ESFZ DURING HISTORICAL TIMES}

Previous studies carried out paleoseismic analysis along the San Vicente segment of the ESFZ (Fig. 2b), the segment responsible for the $2001 M_{\mathrm{w}} 6.6$ earthquake, to assess the recent rupture history of that part of the fault (Canora et al., 2012). To determine the timing of large earthquakes, Canora (2011) identified and dated stratigraphic units that were displaced by the fault (Figs. 3 and 4). Ages for stratigraphic units in the trenches either come from the identification of known airfall tephra in the trenches (e.g., Dull et al., 2001; Hernández, 2004) or by radiocarbon dating of organic samples in the trench sediments (Canora et al., 2012). From this study, at least seven events were identified on the San Vicente segment of the ESFZ in the last $\sim 8 \mathrm{ka}$ (Figs. 3, 4, and 5).

Despite the existence of morphological evidences and eyewitness descriptions of cracking along the fault zone during the February $2001 M_{\mathrm{w}} 6.6$ earthquake, the surface rupture was not observed clearly on most of the trench walls (Fig. 3) (Canora, 2011). This can be explained by the very small vertical offset on the fault that produced an almost pure strike-slip movement, with a maximum horizontal offset of $0.6 \pm 0.1 \mathrm{~m}$ (Canora et al., 2010).
To quantify the single-event displacement associated with the February 2001 earthquake, we excavated a new trench (Buenavista trench) at the place where the surface evidence of slip was more conspicuous and the lithological conditions were more adequate to observe subtle deformations (Fig. 2b). In this trench, the 2001 event is observed as a small fracture with $0.1 \pm 0.05 \mathrm{~m}$ of vertical displacement (Fig. 6) and a net slip of $0.5 \pm 0.1 \mathrm{~m}$. Single-event displacements of older earthquakes identified in the trenches appear to be highly variable, with a net slip ranging from $0.6 \pm 0.1$ to $9.6 \pm 1.5 \mathrm{~m}$ (Fig. 5). It is possible that the largest single-event displacements either represent more than individual events on the San Vicente segment or events that ruptured multiple fault segments (Canora et al., 2012). Although the uncertainties in the estimation of net slip in strike-slip faults using paleoseismic trench data are important, the large single-event displacements $(2.3 \pm 0.5$ and $3.7 \pm 0.7 \mathrm{~m}$ net displacements in Fig. 5), together with empirical relations (Wells and Coppersmith, 1994), suggest the occurrence of at least two earthquakes with $M_{\mathrm{w}}>7$ in the last $1.5 \mathrm{ka}$ (Canora et al., 2012).

\section{HISTORICAL SEISMICITY: BRINGING THE 1719 EARTHQUAKE TO THE MAINLAND}

The historical record in El Salvador covers the last 500 years; thus, it could be possible that one of the events recorded in the paleoseismic analysis could also be recorded in the historical documents. We investigated historical and instrumental seismic catalogs compiled by different national and international institutions (data available online at http://www.snet.gob.sv/ ver/sismologia/registro/estadisticas/, http://neic.usgs.gov/, and http://www.isc.ac.uk/; last accessed December 2013), and we also reviewed the related literature (Bustillo, 1774; Montessus de Ballore, 1884; Díaz, 1930; Lardé-Larín, 1978; Martinez and Maximiliano, 1978; Harlow et al., 1993; White and Harlow, 1993; Peraldo and Montero, 1999; Ambraseys and Adams, 2001; Dewey et al., 2004; White et al., 2004). The spatial distribution of damage used in those studies is not precise enough to provide a unique interpretation of the earthquake source associated with some of the large events, specifically the 1719 earthquake. Bustillo (1774) and Montessus de Ballore (1884) created the first earthquake catalogs for the region, but the majority of the information concerns the largest cities. Later, Martinez and Maximiliano (1978) and Lardé-Larín (1978) introduced more extensive descriptions of earthquake damage into their catalogs, using data from primary sources. Peraldo and Montero (1999) and White et al. (2004), together with Lardé-Larín (1978), have been key sources of data for this study.

+ The penultimate event $\left(M_{\mathrm{w}} 7.1 \pm 0.1\right.$; magnitude derived from regressions of Wells and Coppersmith, 1994) found in the paleoseismic trenches (event 2 in Fig. 3) occurred between A.D. 1485 and 1803. This major event must be registered in the historical catalogs. We hypothesize that this event could be correlated with the 6 March 1719 earthquake recorded in the historical seismic catalogs. Based on the historic 

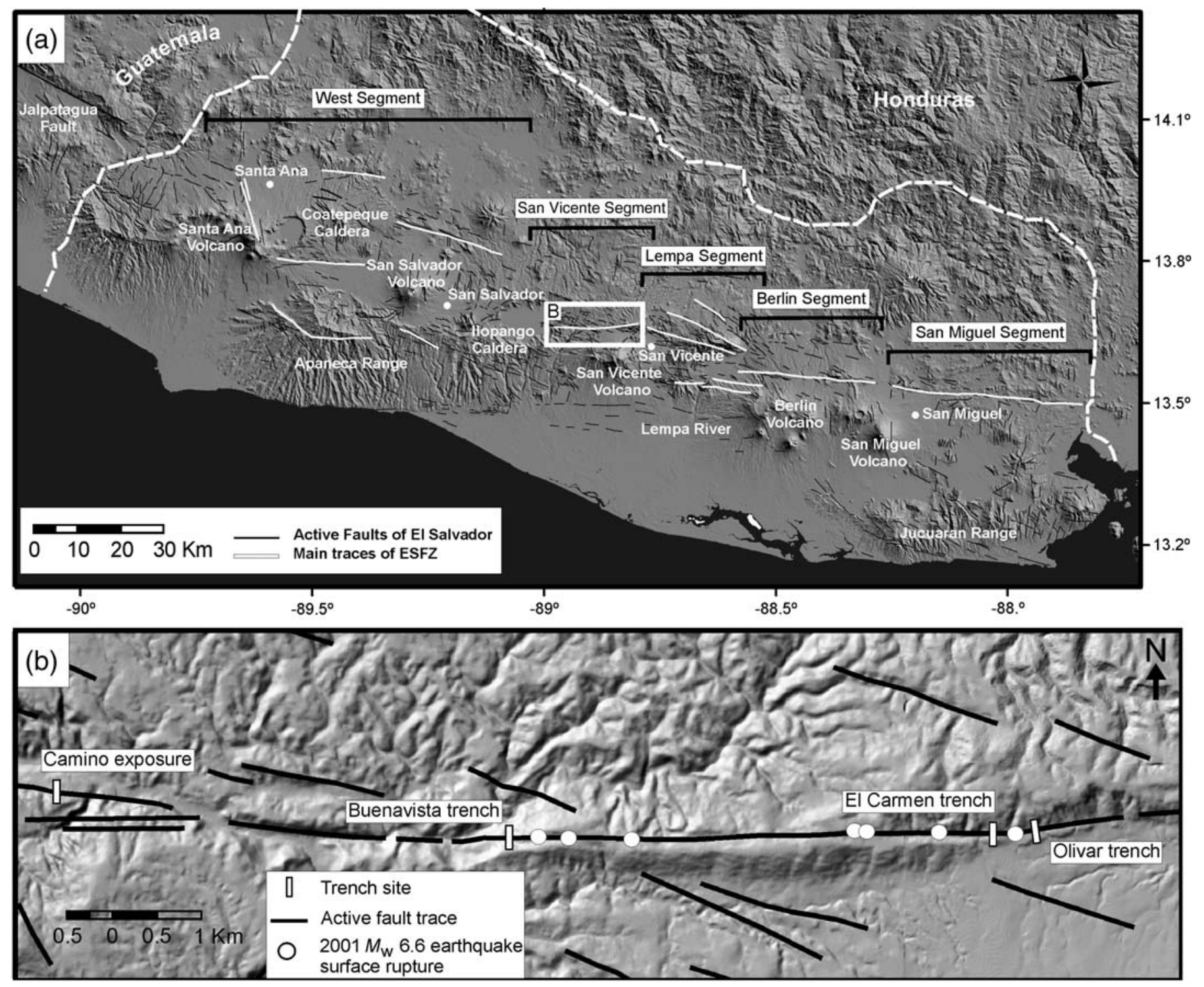

A Figure 2. (a) El Salvador active fault traces (black lines) and main fault traces (white lines), with segments of the ESFZ overlaid onto a $10 \mathrm{~m}$ resolution Digital Terrain Model (DTM) derived from a 1:25,000 topographic map. (b) Fault traces, paleoseismic trench sites, and surface ruptures of the February 2001 earthquake on the San Vicente segment.

records, some authors have proposed that the subduction zone was the source of this earthquake (see Peraldo and Montero, 1999; White et al., 2004), and assigned a $M_{s} 7.2$ based on MMI VII contour area of $9243 \mathrm{~km}^{2}$.

Peraldo and Montero (1999) created an isoseimal map for the 1719 event based on macroseismic parameters taken from the historical sources. To evaluate the validity of this isoseismal map in assessing the position of the seismic source, we analyze the damage distribution produced by the two destructive earthquakes that occurred in 2001 in El Salvador (Fig. 7a,b). The El Salvador Centro de Investigaciones Geotécnicas (CIG) made preliminary isoseismal maps for the January and February 2001 earthquakes that were published on the Internet (http://www .snet.gob.sv/Geologia/Sismologia/isosista_2001.htm, last accessed December 2013). These events can be used as a modern analog of damage distribution for historical events.
The MMI contours of the 13 January $M_{\mathrm{w}} 7.7$ earthquake source, located in the subduction zone, are open to the south of the country (Fig. 7a), whereas the MMI contours of the February $M_{\mathrm{w}} 6.6$ earthquake close around the epicenter are located within the volcanic arc (Fig. 7b). In Figure 7a and 7b, we have included a Kriging interpolation of the peak ground acceleration spatial distribution for the 2001 earthquakes with data taken from Bommer et al. (2002) and Salazar and Seo (2003). The isoseismal geometry is fairly coherent with the spatial distribution of maximum horizontal accelerations recorded. Seismic intensity (MMI) and peak ground acceleration (PGA) are two parameters that describe the degree of ground shaking for earthquakes and depend largely on local factors. No relationship between PGA and MMI exists for El Salvador, and those that best-fit are proposed by Wald et al. (1999) for California and Linkimer (2008) for Costa Rica. 

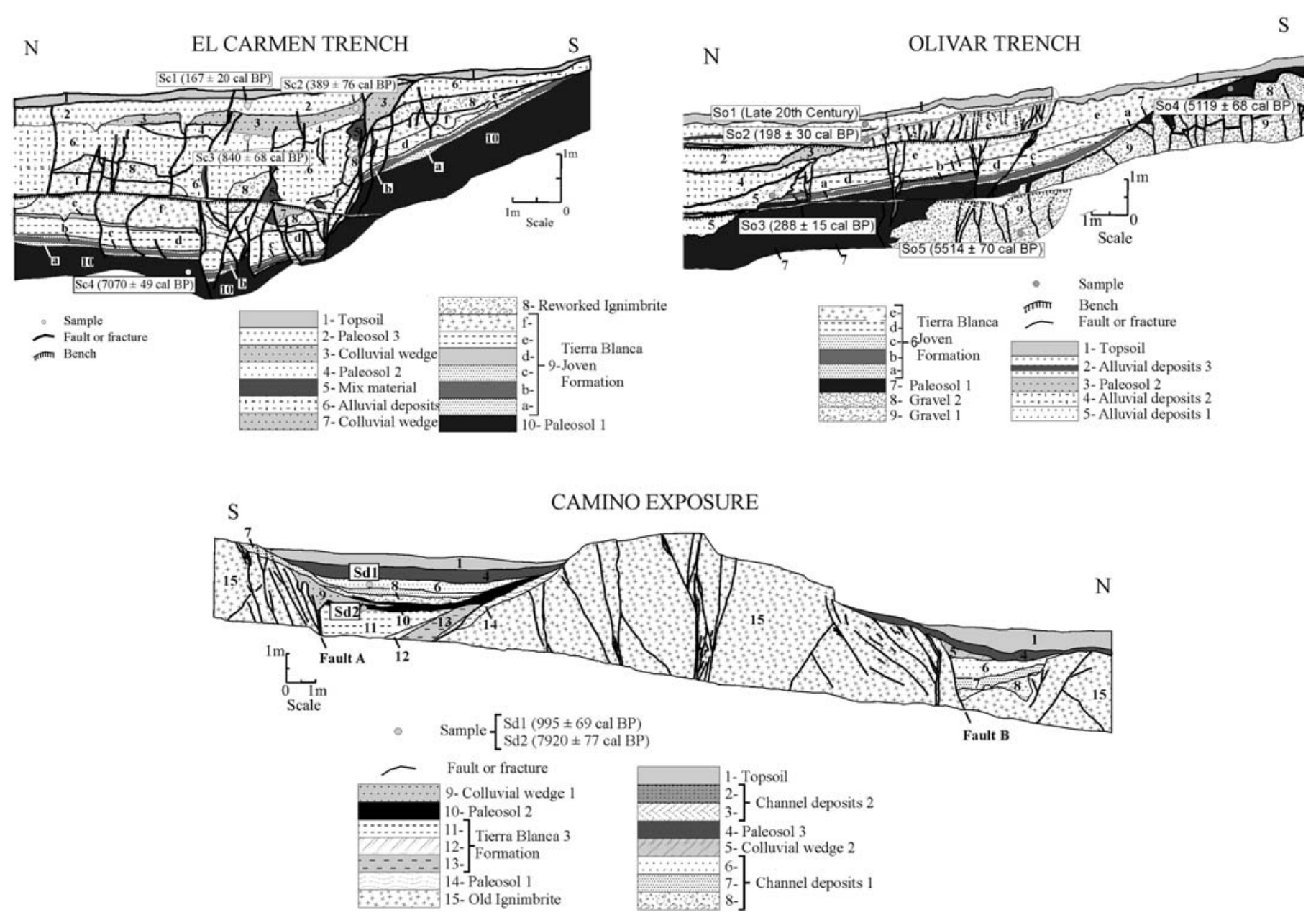

A Figure 3. Logs of the El Carmen and Olivar trenches and the Camino exposure studied on the San Vicente segment of the El Salvador fault zone (ESFZ).

There are some difficulties in relating PGA and MMI. Seismic intensity considers a subjective description of human response to ground shaking and a description of building damage. Therefore, numerous factors may affect the MMI estimate at a particular site. On the other hand, PGA simplifies the complexity of ground shaking without considering factors such as duration, spectral content, and resonance that may considerably affect the MMI estimate. Furthermore, PGA only refers to a maximum value at a single point, as opposed to MMI, which refers to a maximum or average level of damage and earthquake effects throughout an area.

Given these considerations, if we consider the 1719 earthquake as a subduction event, the PGA-MMI relationship indicates that the ground acceleration should have been much higher in the Salvadorian coast than around San Salvador or San Vicente. This would result in extensive damage to coastal communities such as La Libertad and Acajutla. We know that these communities were important commercial harbors at the time of the earthquake (Gerhard, 1960; Fondo de Inversión Social para el Desarrollo Local [FISDL], 2006a; Casa Cultura de la Libertad, 2008; León-Sáenz, 2010); however, we could not find any record of damage at these locations, which leads us to believe that there was no damage or the damage was not significant enough to be recorded.

The contour map defined by Peraldo and Montero (1999) for the 6 March 1719 earthquake shows the MMI VII contour opened to the south, as expected from a source located in the subduction zone (Fig. 7c). However, as already mentioned, we have not found any descriptions of damage or seismic effects in the analyzed historical documents in the southern part of $\mathrm{El}$ Salvador, the area that would be closer to the epicenter assuming a subduction source. Peraldo and Montero (1999) even said that, "looking closely the earthquake damage reports, only the San Salvador and San Vicente area suffered significant damage." Moreover, the isoseismal map and the acceleration map produced by the January $2001 M_{\mathrm{w}} 7.7$ subduction earthquake corroborate that this kind of event should produce significant damage in the coastal region of El Salvador (Fig. 7a). To clarify this inconsistency in the 1719 earthquake damage distribution, we reanalyzed the damage descriptions in the documents and reinterpret the intensity data (Table 1). Peraldo and Montero (1999) and White et al. (2004) indicate an MMI of VIII for Zacatecoluca, referring to White and Cifuentes (1988). This work is unpublished, so we could not identify 


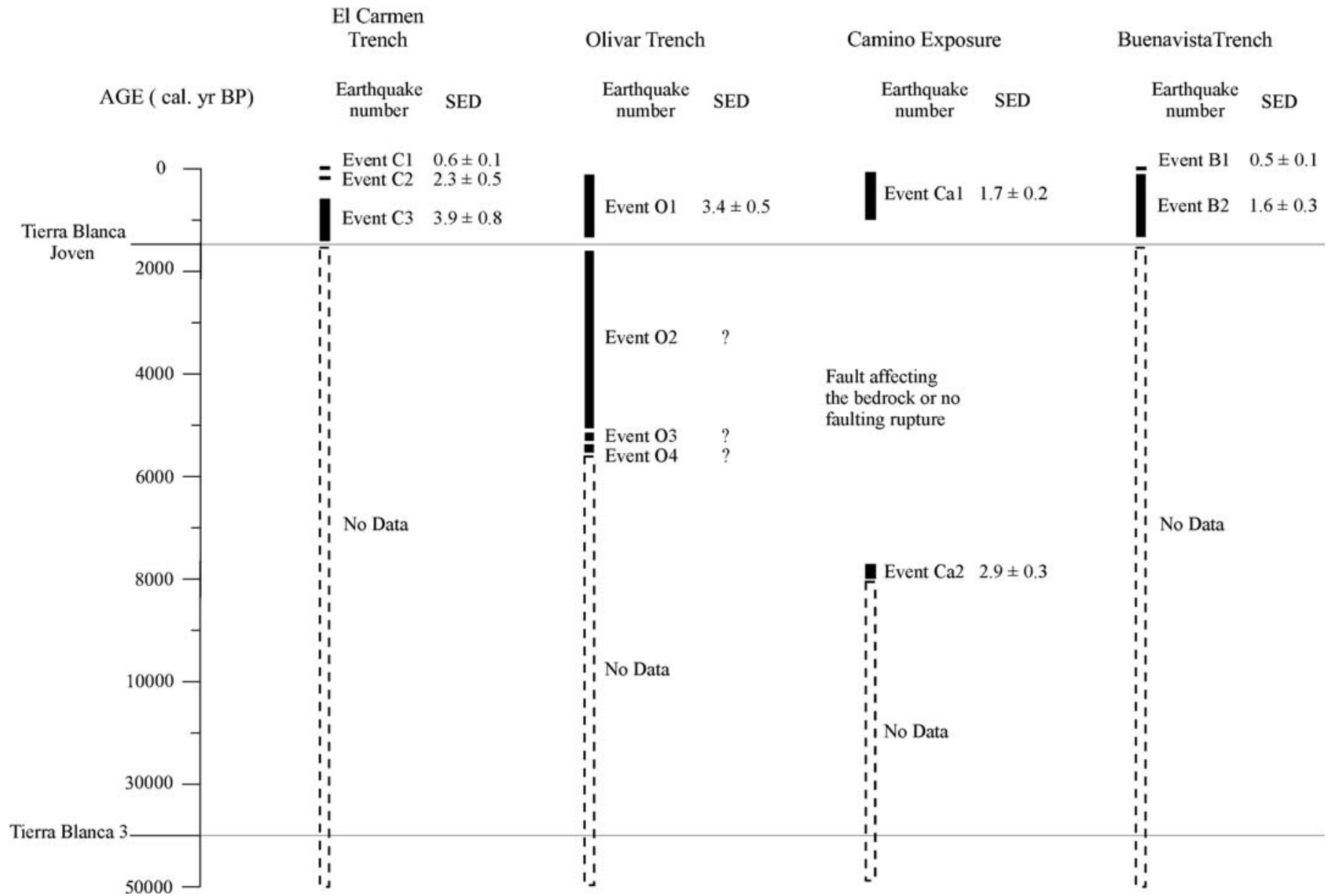

D Figure 4. Summary of the amount and timing of fault ruptures based on the trenches excavated on the San Vicente segment of the ESFZ. (SED. single-event displacement in meters.)

the primary data source for the Zacatecoluca damage. In our research, we have found no reference to damages in this location. We believe that, if there had been an intensity in Zacatecoluca equal to that of San Salvador and San Vicente, there would have been some evidence of damage recorded, since $\mathrm{Za}$ catecoluca by then was an important town in El Salvador, with higher population than San Vicente (Browning, 1975; Cortes y Larraz, 1985; FISDL, 2006b).

Lardé-Larín (1978) and Peraldo and Montero (1999) compiled some descriptions of large fractures, liquefaction zones, and a sulphuric gas leak produced by the 6 March 1719 earthquake, as well as the destruction of numerous buildings, including houses, churches, and monasteries, especially in the cities of San Salvador and San Vicente. These authors also described a large number of foreshocks and aftershocks felt in the area. The number of deaths at the time of the mainshock was unexpectedly low (seven deaths) for the size of the event, possibly as a result of the warning effect resulting from the 150 felt foreshocks (Lardé-Larín, 1978). The earthquake occurred on Monday at about 1:00 a.m. Probably the population, alerted by the foreshocks, was spending the night on the streets at the time of the earthquake. In addition, the event occurred at the end of the dry season, so could have involved a low number of geotechnical effects (e.g., landslides and lateral spreading) associated with the earthquake. In El Salvador, landslides caused by earthquakes raised the number of deaths and injuries (Bommer and Rodríguez, 2002). The absence of large landslides associated with the earthquake of 1719 (if it happened) could also have contributed to the low number of victims.

The descriptions of the 1719 earthquake effects around the cities of San Salvador and San Vicente (Lardé-Larín, 1978; Peraldo and Montero, 1999) are very similar to those reported after the February 2001 earthquake in terms of damage distribution. We constructed a new isoseismal map (Fig. 7d) based on physical effects and damage data found in the literature (Table 1). We used a Kriging interpolation method that is considered an adequate technique in macroseismology (Schenková et al., 2007). In Figure 7d, the isoseismals show slight west-east orientation controlled by the distribution of MMI VIII, which form two spots in the meizoseismal area. This isoseismal geometry is coherent with the position of the ESFZ in the central part of the country and similar to the damage produced by the February 2001 earthquake (Fig. 7b). 


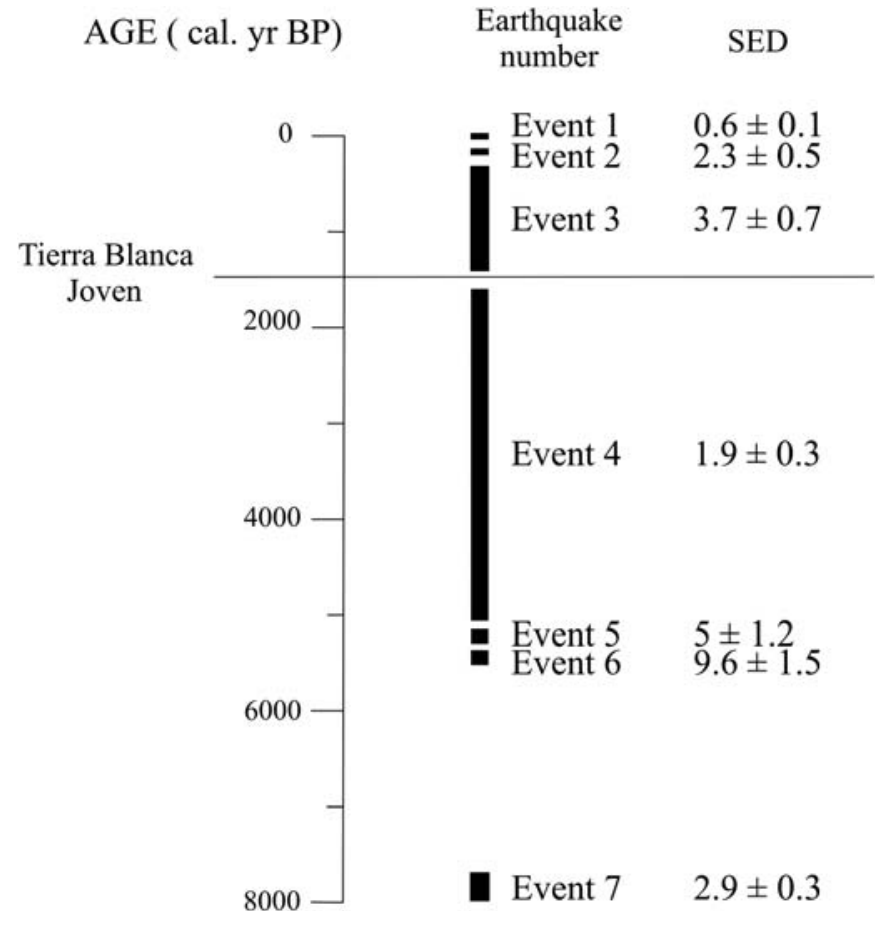

$\Delta$ Figure 5. Summary of the amount and timing of fault ruptures based on the paleoseismic analysis of the trenches excavated on the San Vicente segment of the ESFZ. (SED, single-event displacement in meters.)

\section{DISCUSSION AND CONCLUSIONS}

Active faults in volcanic arc regions usually are not considered capable of generating large-magnitude shallow earthquakes due to mechanical conditions of the crust. However, recent paleoseismological studies on the ESFZ support the proposal that large earthquakes can occur in the central Salvadorian region (Canora et al., 2012). This inconsistency may be related with the kinematics of the ESFZ. In El Salvador, there are evidences of weak subduction coupling (Pacheco et al., 1993; GuzmánSpeziale and Gómez-González, 2006; Álvarez-Gómez et al., 2008; Correa-Mora et al., 2009), hence the state of the stress in the volcanic arc depends on the tensional forces due to the drift of the Caribbean plate toward the east (Álvarez-Gómez et al., 2008). In this context, the ESFZ is a strike-slip transtensional fault that represents a plate's limit between the fore-arc sliver and the Chortis block. Therefore, the seismic behavior of the ESFZ is not that expected for volcanic arc faults, and this could be a reason for the occurrence of $M_{\mathrm{w}} \geq 7$ earthquakes in the El Salvador volcanic arc.

It was not until the occurrence of the February 2001 $M_{\mathrm{w}} 6.6$ earthquake that the ESFZ was defined (Martínez-Díaz et al., 2004), and consequent studies identified it as a source of large strike-slip earthquakes (Canora et al., 2010). Several segments of the ESFZ form part of a large dextral strike-slip system within the active volcanic arc of El Salvador. The $2001 M_{\mathrm{w}} 6.6$ earthquake was a moderate-size event, but it produced significant damage and thousands of injured. Earlier events that

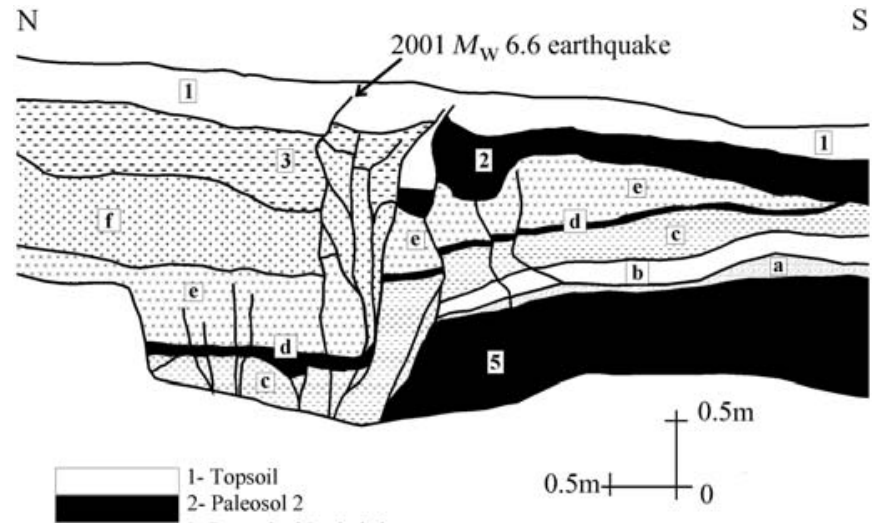

S

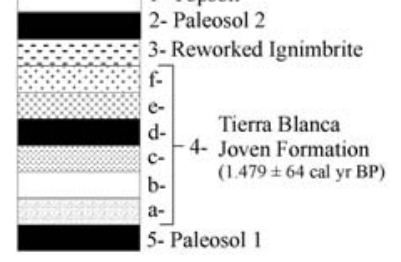

Buenavista Trench

A Figure 6. Paleoseismic Buenavista trench log on the San Vicente segment of the ESFZ.

occurred during the last 1500 years show displacements ranging from $\sim 0.6 \mathrm{~m}$ to as much as $3.7 \mathrm{~m}$, suggesting that the fault is capable of generating surface-rupture earthquakes of $M_{\mathrm{w}}>$ 7.0 (Canora et al., 2012). An example of these large events might be the 6 March 1719 earthquake.

Peraldo and Montero (1999) calculated a magnitude $M_{\mathrm{s}} 7.2$ for the 1719 earthquake, assuming that it was a subduction intraplate event and entering a maximum intensity value of VIII. They claim that large surface earthquakes in the subduction zone generate higher intensities in the coastal zone and decrease in intensity further inland. We agree with this statement; however, in the case of the 1719 earthquake, we found no evidence that the maximum intensities occur in the coast and decrease inland, as there are several ancient populations in the coastal zone (e.g., La Libertad and Acajutla) in which no damage from this event was reported.

Comparing the MMI VII contour area for the March 1719 earthquake from our isoseismal map (Fig. 7d) with that of the February 2001 earthquake (Fig. 7b), we can conclude that the 1719 event must have had a greater magnitude than $M_{\mathrm{w}}$ 6.6. To attempt to determine the magnitude for the 1719 earthquake, we analyzed the empirical relationships between the area covered by the isoseismal and the magnitude defined in North and Central America (Bollinger et al., 1993; Suter et al., 1996), and we used the February 2001 earthquake to check its validity for El Salvador. We found that these relationships clearly underestimate the magnitude, which may be explained by the greater energy attenuation in the Salvadorian volcanic arc, probably due to high structural complexity bound to a strong lithological anisotropy in surface levels. The relationship defined by Bollinger et al. (1993) for crustal earthquakes is the best fit for El Salvador. However, this relationship indicates a magnitude of about 6.0 if we use the MMI VII area, and even lower if we use the MMI VI area, for the February $2001 M_{\mathrm{w}} 6.6$ 

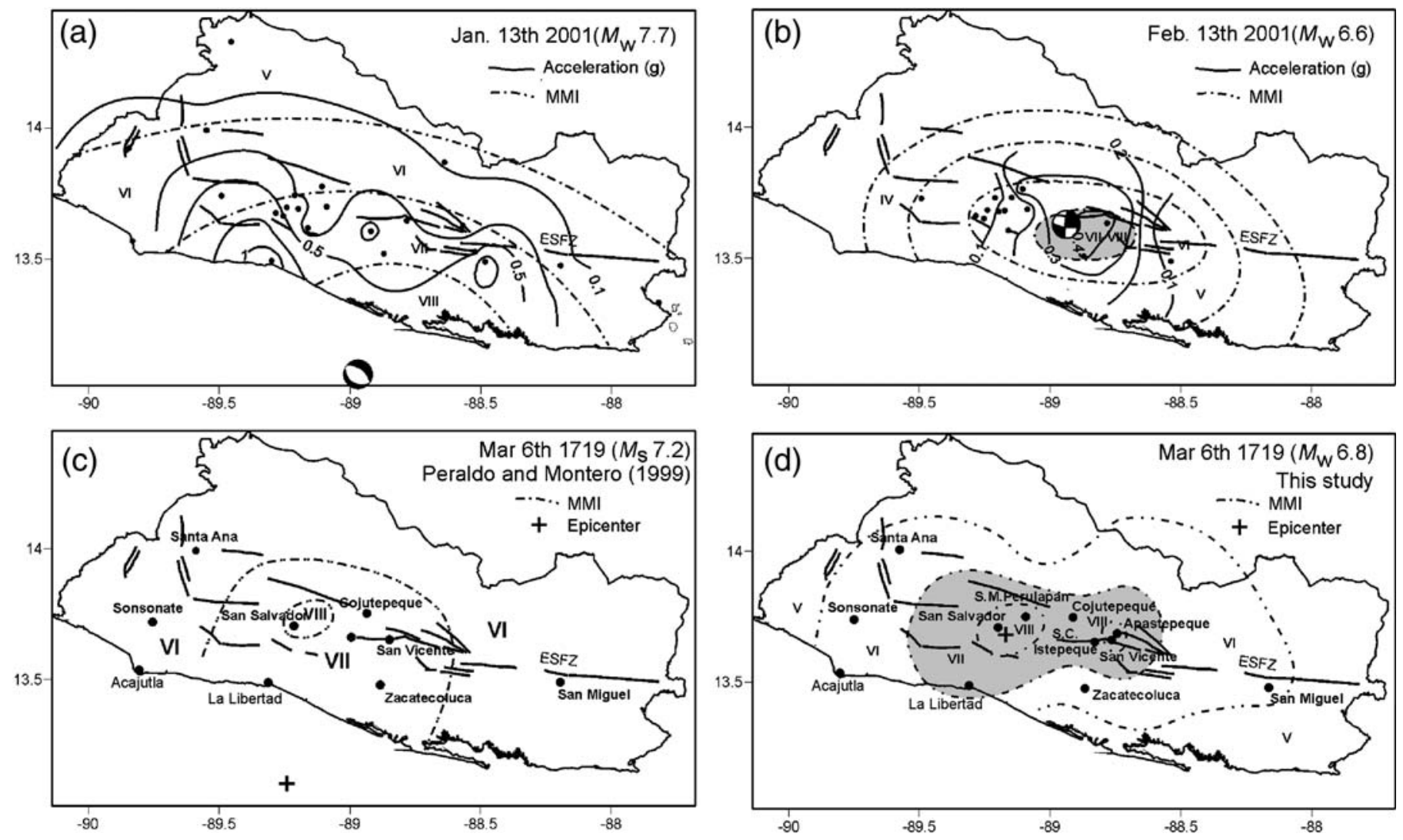

A Figure 7. (a) The isoseismal map for modified Mercalli intensity (MMI) distribution for the January 2001 El Salvador earthquake, after CIG (2001), and peak ground acceleration map based on Salazar and Seo (2003) data. (b) The isoseismal map for MMI distribution for the February 2001 El Salvador earthquake after CIS (2001), and peak ground acceleration map based on Salazar and Seo (2003) data. (c) The reported MMI distribution and epicentral location from the 6 March 1719 El Salvador earthquake from Peraldo and Montero (1999). (d) The isoseismal map from this study based on the MMI distribution reported from the 1719 El Salvador event, with epicentral location proposed by Lardé-Larín (1978). Note the difference in the MMI VII contour areas between this event and the February $2001 M_{\mathrm{w}} 6.6$ event. Thicker black lines are the main faults within the ESFZ for the four maps.

\begin{tabular}{|c|c|c|}
\hline \multicolumn{3}{|c|}{$\begin{array}{l}\text { Table } 1 \\
\text { Information from Felt Reports to Estimated Relative Intensities Associated with the } 6 \text { March } 1719 \text { Earthquake }\end{array}$} \\
\hline Area & Description of Damage & Earthquake Intensity (MMI) \\
\hline San Salvador & Entirely ruined & VIII \\
\hline San Vicente & Entirely ruined & VIII \\
\hline San Miguel & Slightly damaged & $\mathrm{VI}$ \\
\hline Sana Ana & Slightly damaged & VI \\
\hline Apastepque & Ruined & VII-VIII \\
\hline San Cayetano Istepeque & Very badly affected & VII \\
\hline San Martín Perulapán & Ruined & VII-VIII \\
\hline Zacatecoluca & Slightly damaged & VI \\
\hline Cojutepeque & Very badly affected & VII \\
\hline Sonsonate & Cracked, minor damaged & VI \\
\hline
\end{tabular}



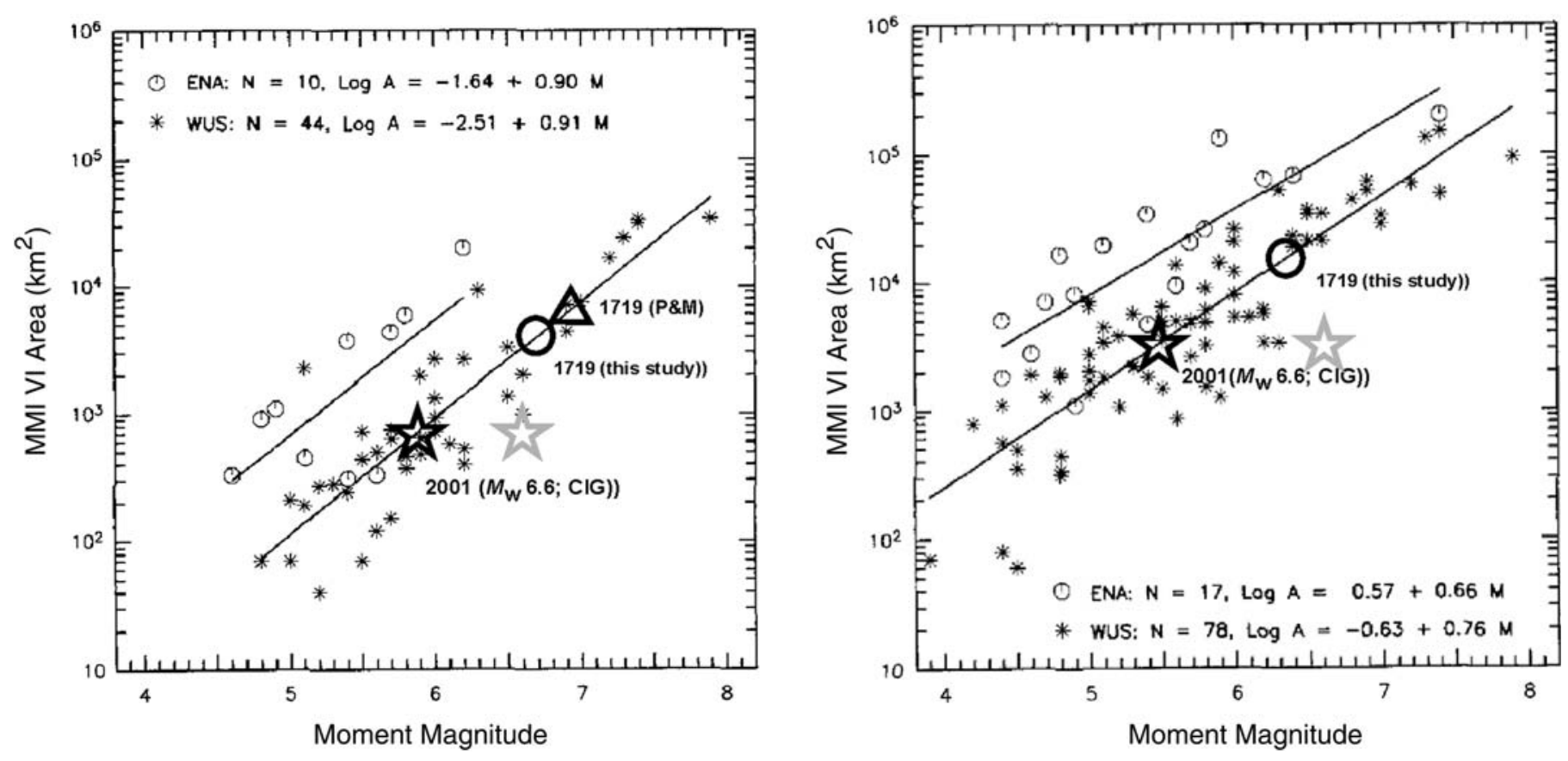

- Figure 8. Empirical relationship between the moment magnitude and the MMI VII and VI areas from Bollinger et al. (1993). Large black stars represent the February $2001 \mathrm{El}$ Salvador earthquake according to the empirical relationship, and gray stars show the real magnitude and isoseismal area for this event. The large circles represent the March 1719 earthquake according to data from this study, and the triangle shows this same event according to Peraldo and Montero (1999) data.

El Salvador earthquake (Fig. 8). Using the Bollinger et al. (1993) relationship, we calculated an $M_{\mathrm{w}}$ 6.6-6.8 for the 1719 event (Fig. 8) for the isoseismal areas proposed in this paper (Fig. 7d). It is true that the scatter of the data used by Bollinger et al. (1993) is significant, so the real magnitude for the February 2001 El Salvador earthquake can be included in the standard deviation associated with these relationships. Despite this, we consider these empirical relationships under- estimate the magnitude in El Salvador; therefore, the $1719 M_{\mathrm{w}}$ event may have reached a moment magnitude greater than 6.8 , and it is possible that it was greater than 7.0.

The isoseismal map from this study indicates that the source of this earthquake could have been a large $\left(M_{\mathrm{w}} \geq 6.8\right)$, shallow ( $<20 \mathrm{~km}$ depth) rupture within the volcanic arc of El Salvador, and this is coherent with a fault source located in the ESFZ. The 6 March 1719 earthquake could correspond with

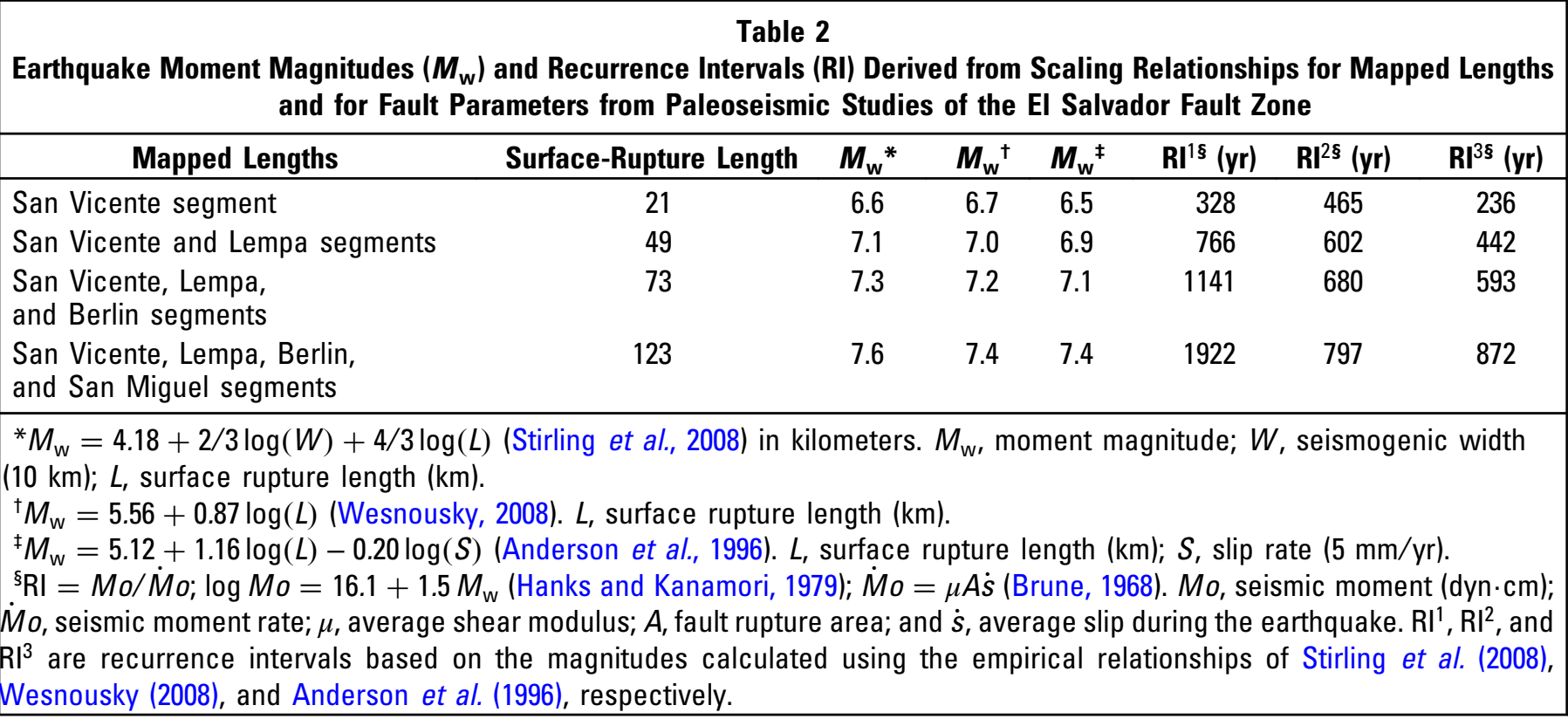


one of the ruptures identified in the San Vicente segment of the ESFZ due to its age and displacement.

In order to improve the seismic-hazard assessment in the area, we calculated a range of expected maximum magnitudes and recurrence intervals for large earthquakes on the ESFZ (Table 2) based on available information, such as fault length and fault displacements (Canora et al., 2010), events recognition, measurement and dating (Canora et al., 2012), and fault slip rates (C. Canora et al., unpublished manuscript, 2013). Once again, we used the February 2001 earthquake to check the validity of the existing empirical relationship and those that best fit for El Salvador are included in Table 2. Recurrence intervals arising from the empirical relationships for large earthquakes are consistent with the data obtained from paleoseismic studies (recurrence interval of 750 years for $M_{\mathrm{w}}>7$ earthquakes; Canora et al., 2012).

Earthquake hazard and risk in the vicinity of the ESFZ should be analyzed considering these new insights. Especially given that some of the faults that form this structure are found in the vicinity of large cities such as San Salvador, with a population of $>2$ million people. $\mathbf{<}$

\section{ACKNOWLEDGMENTS}

This research was financed by the Spanish Ministry of Science and Education through the research project "GEOTACTICA: Analysis of the active tectonics and volcano-tectonic interactions in the El Salvador using geological, geotechnical and geophysical data" (Reference Number CGL2009-14405C02-02) and by Geothermal Project (GRN) of the New Zealand Ministry for Science and Innovation. We are grateful to colleagues at Dirección General del Observatorio Ambiental (DGOA-MARN), Manuel Díaz and Douglas Hernández, for their assistance. The first author acknowledges financial support for this publication provided by a postdoctoral contract of the Universidad Complutense de Madrid, Spain.

\section{REFERENCES}

Alvarado, D., C. DeMets, B. Tikoff, D. Hernández, T. F. Wawrzyniec, C. Pullinger, G. Mattioli, H. L. Turner, M. Rodriguez, and F. CorreaMora (2011). Forearc motion and deformation between El Salvador and Nicaragua: GPS, seismic, structural, and paleomagnetic observations, Lithosphere 3, 3-21.

Álvarez-Gómez, J. A. (2009). Tectónica active y geodinámica en el norte de Centro América, Ph.D. thesis, Geodynamics Department, Universidad Complutense de Madrid, Spain.

Álvarez-Gómez, J. A., P. T. Meijer, J. J. Martínez-Díaz, and R. Capote (2008). Constraints from finite element modeling on the active tectonics of northern Central America and the Middle America trench, Tectonics 27, 1-12.

Ambraseys, N. N., and R. D. Adams (2001). The Seismicity of Central America: A Descriptive Catalogue 1898-1995, Imperial College Press, London, United Kingdom, 309 pp.

Anderson, J. G., S. G. Wesnousky, and M. W. Stirling (1996). Earthquake size as a function of fault slip rate, Bull. Seismol. Soc. Am. 86, 683-690.

Bollinger, M., C. Chapman, and M. S. Sibol (1993). A comparison of earthquake damage areas as a function of magnitude across the United States, Bull. Seismol. Soc. Am. 83, 1064-1080.
Bommer, J. J., and C. E. Rodríguez (2002). Earthquake-induced landslides in Central America, Eng. Geol. 63, nos. 3/4, 189-220.

Bommer, J., B. Benito, M. Ciudad-Real, A. Lemoine, M. López-Menjivar, R. Madariaga, J. Mankelow, P. Mendez-Hasbun, W. Murphy, M. Nieto-Lovo, C. Rodríguez, and H. Rosa (2002). The Salvador earthquakes of January and February 2001: Context, characteristics and implications for seismic risk, Soil Dyn. Earthq. Eng. 22, 389-418.

Browning, D. (1975). El Salvador, Landscape and Society, Oxford University Press, London, 525 pp.

Brune, J. N. (1968). Seismic moment, seismicity, and rate of slip along major fault zones, J. Geophys. Res. 73, 777-784.

Buforn, E., A. Lemoine, A. Udias, and R. Madariaga (2001). Mecanismo focal de los terremotos de El Salvador, in Memorias 2nd Congreso Iberoamericano de Ingeniería Sismica, J. M. Martínez-Guevara (Editor), Madrid, Spain, 115-118 (in Spanish).

Bustillo, J. G. (1774). Razón puntual de los estragos más memorables y de los estragos y daños que ha padecido la Ciudad de Guatemala y su vecindario desde que se fundó, Mixco, Guatemala, 55 pp. (in Spanish).

Canora, C. (2011). Análisis sismotectónico, neotectónico y paleosísmico de la zona de falla de El Salvador, Centro América, Ph.D. thesis, Geodynamics Department, Universidad Complutense de Madrid, Spain, $192 \mathrm{pp}$.

Canora, C., J. J. Martínez-Díaz, P. Villamor, K. Berryman, J. A. ÁlvarezGómez, C. Pullinger, and R. Capote (2010). Geological and seismological analysis of the 13 February $2001 M_{\mathrm{w}} 6.6$ El Salvador earthquake: Evidence for surface rupture and implications for seismic hazard, Bull. Seismol. Soc. Am. 100, 2873-2890.

Canora, C., P. Villamor, J. J. Martínez-Díaz, K. Berryman, J. A. ÁlvarezGómez, R. Capote, and W. Hernández (2012). Paleoseismic analysis of the San Vicente segment of the El Salvador fault zone, El Salvador, Central America, Geologica Acta 10, 1-20.

Casa Cultura de la Libertad (2008). El Salvador Histórico. El Muelle, http://www.elsalvadorhistorico.org/articulos/antropologia-e-historia/ 13-el-muelle.html (last accessed December 2013).

Centro de Investigaciones Geotécnicas (CIG) (2001). Servicio Geológico Nacional, http://www.snet.gob.sv/Geologia/Sismologia/isosista_2001 .htm (last accessed November 2013) (in Spanish).

Correa-Mora, F., C. DeMets, D. Alvarado, H. L. Turner, G. Mattioli, D. Hernandez, C. Pullinger, M. Rodriguez, and C. Tenorio (2009). GPS-derived coupling estimates for the Central America subduction zone and volcanic arc faults: El Salvador, Honduras and Nicaragua, Geophys. J. Int. 179, 1279-1291.

Cortes y Larraz, P. (1958). Descripción Geográfico-Moral de la Diócesis de Goathemala. Tomos, I y II, Tipografía Nacional, Biblioteca, Guatemala (in Spanish).

Dewey, J. W., and G. Suárez (1991). Seismotectoics of Middle America, in Neotectonics of North America, D. B. Slemmons, E. R. Engdahl, M. D. Zoback, and D. B. Blackwell (Editors), Geological Society of America, 309-321.

Dewey, J. W., R. A. White, and D. A. Hernández (2004). Seismicity and tectonic of El Salvador, in Natural Hazards in El Salvador, W. I. Rose, J. J. Bommer, D. L. López, M. J. Carr, and J. J. Major (Editors), Geological Society of America Special Paper, Vol. 375, 363-378.

Díaz, V. (1930). Conmociones Terrestres de América Central, J. Ibarra (Editor), Guatemala, 267 pp. (in Spanish).

Dull, R., J. R. Southon, and P. Sheets (2001). Volcanism, ecology and culture: A reassessment of the Volcán Ilopango TBJ eruption in the southern Maya realm, Latin American Antiquity 12, 25-44.

Fondo de Inversión Social para el Desarrollo Local (FISDL) (2006a). Acajutla, http://www.fisdl.gob.sv/servicios/en-linea/ciudadano/conoce-tumunicipio/sonsonate/678-636 (last accessed December 2013).

Fondo de Inversión Social para el Desarrollo Local (FISDL) (2006b). Zacatecoluca, http://www.fisdl.gob.sv/servicios/en-linea/ciudadano/ conoce-tu-municipio/la-paz/742-696 (last accessed December 2013).

Gerhard, P. (1960). Pirates on the West Coast of New Spain, 1575-1742, A. H. Clark Co., Glendale, California, 274 pp. 
Guzmán-Speziale, M., and J. M. Gómez-González (2006). Seismic strain rate along the Middle America trench reveals significant differences between Cocos-North American and Cocos-Caribbean convergence, Geophys. J. Int. 166, 179-185.

Hanks, T. C., and H. Kanamori (1979). A moment-magnitude scale, J. Geophys. Res. 84, 2348-2350.

Harlow, D. H., R. A. White, M. J. Rymer, and S. Alvarez (1993). The San Salvador earthquake of 10 October 1986 and its historical context, Bull. Seismol. Soc. Am. 83, 1143-1154.

Hernández, W. (2004). Características geomecánicas y vulcanológicas de las tefras de Tierra Blanca Joven, Caldera de Ilopango, Master Thesis, Universidad Politécnica de Madrid, Spain (in Spanish).

Lardé-Larín, J. (1978). El Salvador: inundaciones e incendios, erupciones y terremotos, Biblioteca de Historia Salvadoreña, 397 pp. (in Spanish).

León-Sáenz, J. (2010). Incursiones contra el comercio colonial: evidencias para el Pacifico centroamericano, 1570-1825, Boletín AFEHC No47, http://afehc-historia-centroamericana.org/index.php?action =fi_aff\&id=2529 (last accessed December 2013) (in Spanish).

Linkimer, L. (2008). Relationship between peak ground acceleration and modified Mercalli intensity in Costa Rica, Revista Geológica de América Central 38, 81-94.

Martinez, H., and A. Maximiliano (1978). Cronología sísmica y eruptiva de la República de El Salvador a partir de 1520, Ministerio de Obras Públicas, Centro de Investigaciones Geotécnicas, 40 pp.

Martínez-Díaz, J. J., J. A. Álvarez-Gómez, B. Benito, and D. Hernández (2004). Triggering of destructive earthquakes in El Salvador, Geology 32, 65-68.

Montessus de Ballore, F. (1884). Sur les tremblements de terre et les éruptions volcaniques dans le Centre Amerique: depuis la conquête espagnole jusqu'a nos jours, Société des Sciences Naturelles de Saone-et-Loire (Editor), Jobard, Dijon, 293 pp. (in French).

Pacheco, J. F., L. R. Sykes, and C. H. Scholz (1993). Nature of seismic coupling along simple plate boundaries of the subduction type, $J$. Geophys. Res. 98, 14133-14159.

Peraldo, G., and W. Montero (1999). Sismología Histórica de América Central, Instituto Panamericano de Geografía e Historia, México, Vol. 513, 1-347 (in Portuguese).

Salazar, W., and K. Seo (2003). Earthquake disasters of 13 January and 13 February 2001, El Salvador, Seismol. Res. Lett. 74, 420-439.

Schenková, Z., V. Schenk, I. Kalogeras, R. Pichl, P. Kottnauer, C. Papatsimba, and G. Panopoulou (2007). Isoseismal maps drawing by the Kriging method, J. Seismol. 11, 121-129.

Stirling, M. W., M. C. Gerstenberger, N. J. Litchfield, G. H. McVerry, W. D. Smith, J. Petting, and P. Barnes (2008). Seismic hazard of the Canterbury region, New Zealand: New earthquake source model and methodology, Bull. New Zeal. Soc. Earthq. Eng. 41, 51-67.

Suter, M., M. Carrillo-Martínez, and O. Quintero-Legorreta (1996). Macroseismic study of shallow earthquakes in the central and eastern parts of the Trans-Mexican volcanic belt, Mexico, Bull. Seismol. Soc. Am. 86, 1952-1963.

Wald, D. J., V. Quitoriano, T. H. Heaton, and H. Kanamori (1999). Relationship between peak ground acceleration, peak ground velocity, and modified Mercalli intensity in California, Earthq. Spectra 15, 557-564.

Wells, D. L., and K. L. Coppersmith (1994). New empirical relations among magnitude, rupture length, rupture width, rupture area and surface displacement, Bull. Seismol. Soc. Am. 84, 974-1002.

Wesnousky, S. G. (2008). Displacement and geometrical characteristics of earthquake surface ruptures: Issues and implications for seismichazard analysis and the process of earthquake rupture, Bull. Seismol. Soc. Am. 98, 1609-1632.

White, R., and I. Cifuentes (1988). Seismic history of the Middle America trench spanning the Guatemala triple junction and an earthquake forecast for western El Salvador (unpublished).

White, R. A., and D. H. Harlow (1993). Destructive uppercrustal earthquakes of Central America since 1900, Bull. Seismol. Soc. Am. 83, $1115-1142$.

White, R. A., D. H. Harlow, and S. Álvarez (1987). The San Salvador earthquake of October 10, 1986: Seismological aspects and other recent local seismicity, Earthq. Spectra 3, 419-434.

White, R. A., J. P. Ligorría, and I. L. Cifuentes (2004). Seismic history of the Middle America subduction zone along El Salvador, Guatemala, and Chiapas, Mexico: 1526-2000, in Natural Hazards in El Salvador, W. I. Rose, J. J. Bommer, D. L. López, M. J. Carr, and J. J. Major (Editors), Geological Society of America Special Paper, Vol. 375, 379-396.

Carolina Canora Departamento de Física Instituto Superior Técnico de Lisboa Av. Rovisco Pais 1 1049-001 Lisboa, Portugal carolina.catalan@ist.utl.pt

José J. Martínez-Díaz Juan M. Insua-Arévalo José A. Álvarez-Gómez Jorge Alonso-Henar Ramón Capote-Villar Departamento de Geodinámica Universidad Complutense de Madrid C/ Jose A. Novais 2 28042 Madrid, Spain

Pilar Villamor GNS Science-Te Pu Ao 1 Fairway Drive, Avalon PO Box 5762 Lower Hutt, New Zealand 